\title{
THE EFFECT OF MAKING SUMMARY ON STUDENTS' WRITING ACHIEVEMENT OF OF THE STUDENTS OF SMA SWASTA MELATI BINJAI
}

\author{
Juliantina \\ STKIP Budidaya Binjai
}

\begin{abstract}
Penelitian ini bertujuan untuk mengetahui efektivitas membuat rangkuman dalam prestasi siswa dalam menulis dan untuk mengetahui apakah membuat rangkuman mampu meningkatkan prestasi siswa secara tertulis pada siswa kelas sepuluh SMA Swasta Melati Binjai 2017/2018. Dalam penelitian ini, menerapkan ringkasan pembuatan sebagai variabel independen $(\mathrm{X})$ dan prestasi belajar siswa dalam menulis sebagai variabel dependen $(\mathrm{Y})$, dengan hipotesis: ada pengaruh yang signifikan dari penerapan membuat ringkasan pada prestasi siswa secara tertulis pada siswa kelas sepuluh 2017/2018 kelas sepuluh dari SMA Swasta Melati Binjai. Populasi penelitian ini adalah siswa kelas XI SMA Swasta Melati Binjai tahun 2017/1988 yang terdiri dari 30 siswa. Sampel diambil dengan menggunakan semua sampling, total sampel adalah 30 siswa. Penulis menggunakan tes sebagai instrumen pengumpulan data. Data dianalisis dengan menggunakan rumus uji-t. Berdasarkan analisis data, ditemukan bahwa nilai t-diamati (untuk) lebih tinggi dari nilai t-tabel, (tobserved $=23.2>$ ttable $=2.04$ ). Oleh karena itu, hipotesis yang diajukan oleh penulis diterima. Dengan kata lain, ada pengaruh yang signifikan dari penerapan membuat ringkasan pada prestasi siswa secara tertulis.
\end{abstract}

Key Word : Making Summary and Writing Achievement

\section{INTRODUCTION}

Writing is one of the language skills that should be acquired in learning a language. It is deliberate act which leads the mind to do several things. For instance, writing contains some information that will be informed to readers. This means that the writer should have some knowledege to make the product of writing interesting. Writing also means a process of communication that conveys ideas and opinions in a written form which suggests that the writer and readers should have similar understanding of what is written. There will be confusion on the part of the readers if the ideas and opinions are not clearly described.

In fact, the majority of students usually refuse to write. It caused they do not know what to write. The writing skill is considered to be the most difficult of the language skills for Indonesian students. The first stage in learning language is by hearing it.

Not all of students writing in English to send a text. In spite of the fact that writing is very important, especially for Indonesian students who should master four language skills that have to be mastered since junior high schools, the writing skill is considered as a difficult assignment.

What makes writing so important : Writing is the primary basis upon which your work, your learning, and your intellect will be judged-in college, in the workplace, and in the community. Writing expresses who you are as a person. Writing promotes your ability to pose worthwhile questions. Writing helps others give you feedback. Writing is an essential job skills. Their results of English assigment were not as good as the other English language skill results.

There are still many reasons why writing English is difficult. "There are many peoples cannot write. They feel confused when they have to write because they do not even know how to get started to write P. Elbow \& P. Belanoff. Being A Writer: A Community of Writers Revisited. (New York: McGraw Hill Higher Education, 2003) p. 81. . Getting started to write can be very difficult J.D. Day. Teaching Summarization Skills: A Comparison of Training 
Methods. (Unpublished doctoral dissertation, University of Illinois, Urbana, 2001) p. 27. .

Based on the first observation that the writers has done, these conditions happened in Class X students of SMA Swasta Melati in Binjai.This problem is caused by lack of willingness to learn, learning time is very less, and learning the wrong way. Another problem comes from the teacher used a conventional technique in the teaching process.

The objective of this study is to find out whether using making summary affects on the students'writing achievement of 2017/2018 Tenth Grade Students of SMA Swasta Melati Binjai.

\section{METHOD}

This study was conducted at SMA Swasta Melati Binjai in Academic Year 2017/2018.Author choosed this school for research location because it has never done this research.The implementation plan of this research was conducted in the first semester of the academic year 2017/2018.

Method selected in accordance with the purpose of the study, every researcher needs identified whether the data held fulfill the basic assumptions that must be met each technique, the early stages are further refine the selection (screening) of data, which identify behavioral data, the presence or absence of extreme values (outliers), the complete absence data and statistical description of the data they hold.

Population is the object to be examined. The population in this study is all students of class $X$ of SMA Swasta Melati Binjai in Academic Year 2017/2018 as many as 60 students from 2 Classes can be seen in the following table:

Table 3.1

The Population of Study

\begin{tabular}{|l|l|l|}
\hline No. & \multicolumn{1}{|c|}{ Class } & \multicolumn{1}{c|}{ Total Students } \\
\hline 1. & $\mathrm{X}-\mathrm{A}$ & 30 Students \\
\hline 2. & $\mathrm{X}-\mathrm{B}$ & 30 Students \\
\hline & & 60 Students \\
\hline
\end{tabular}

The sample is a sample or a portion of the population. Suharsimi Arikunto reveal "when the subject is less than 100 , better taken all that research is population research, Furthermore, if a large number of subjects can be taken between $10-15 \%$ or $20-25 \%$ or more." So the researchers takes samples of this research is that there are students in class X-A and $\mathrm{X}-\mathrm{B}$, can be seen in the following table :

Table 3.1

The Sample of Study

\begin{tabular}{|l|l|l|l|}
\hline No. & \multicolumn{1}{|c|}{ Class } & \multicolumn{1}{|c|}{ Categories } & \multicolumn{1}{c|}{$\begin{array}{c}\text { Total } \\
\text { Students }\end{array}$} \\
\hline 1. & X-A & $\begin{array}{l}\text { Experiment } \\
\text { Class }\end{array}$ & 30 Students \\
\hline 2. & X-B & Control Class & 30 Students \\
\hline & \multicolumn{2}{|c}{ TOTAL } & 60 Students \\
\hline
\end{tabular}

a) Independent Variables

Independent variables are variables that affect. The independent variables in this study is Scanning Technique, with the code (X).

b) Dependent Variable

The dependent variable is the variable that is affected or which investigated the relationship. In this study were used as the dependent variable is Reading Comprehension, the code (Y).

The writer were used the test to collect the data. The test was given to control and experiment class. The test in the control class has done in order to know the basic ability students in reading comprehension without using metode technique, and the test in experiment class was given in order to know the influence and the effectiveness of using Scanning Technique on students achievement of reading comprehension.

To obtain optimal data more accurate, the writer using the test in this study as a research instrument. The test used is a multiple choice about reading as many 20 item test. If one question is true, so the score is 5. And if all the questions are true, so the score is 100 .

To calculate the significant influence of the application of scanning techniqueon the students reading comprehension ability, then test the difference between two average that the $\mathrm{t}$ test one hand, the right hand with the formula $t$ test. $t$ test were used for the variance 
between the two groups to say homogeneous as follows :

$$
\mathrm{t}_{\text {count }}=\frac{\mathrm{X}_{\mathrm{e}}-\mathrm{X}_{\mathrm{K}}}{\mathrm{s}}
$$

with $S_{\mathrm{gab}}=\frac{\left(\mathrm{n}_{\mathrm{e}}-1\right) \mathrm{S}_{\mathrm{e}}^{2}+\left(\mathrm{n}_{\mathrm{k}}-1\right) \mathrm{S}_{\mathrm{e}}^{2}}{\mathrm{n}_{\mathrm{e}}+\mathrm{n}_{\mathrm{k}}-2}$

If the heterogeneous said the formula used is as follows:

$$
\begin{aligned}
& \mathrm{t}_{\text {count }}=\frac{X_{1}-X_{2}}{\sqrt{\frac{s_{1}^{2}}{n_{1}}+\frac{s_{1}^{2}}{n_{2}}}} \\
& \mathrm{t}_{\text {table }}=\frac{\left(\frac{s_{1}^{2}}{n_{1}}\right) t_{1}+\left(\frac{s_{1}^{2}}{n_{2}}\right)}{\left(\frac{s_{1}^{2}}{n_{1}}+\frac{s_{1}^{2}}{n_{2}}\right)}
\end{aligned}
$$

description :

$\mathrm{X}_{1}=$ average score pretest results

$\mathrm{X}_{2}=$ average posttest score results

$S_{e}^{2}=$ Average pretest results

$S_{k}^{2}=$ Average posttest results

combined

$S_{\mathrm{gab}}=$ standard deviation of the

$\mathrm{n}_{1}=$ number of group members pretest

$\mathrm{n}_{2}=$ number of group members posttest

$t$ ratio calculation results further

confirmed the value $t_{\text {critics }}$ at $5 \%$ significant level of freedom $\mathrm{df}=\mathrm{n} 1+\mathrm{n} 2$

- 2 then $\mathrm{t}$ table $=\mathrm{t}((1-1 / 2 \alpha)(\mathrm{dk})$.

Criteria testing accept Ha if $t_{\text {count }}>t_{\text {table }}$.

Value $t$ with significance level of $5 \%$ or 0.05 .

\section{RESULT AND DISCUSSION}

This research was conducted at SMA Swasta Melati Binjai using experimental research methods, where the techniques used in data collection control class and experimental class. Before students are given the material, the first students were given a test as a measure of students' basic ability on reading comprehension.

\begin{tabular}{|l|c|c|c|}
\hline \multicolumn{1}{|c|}{ Class } & $\mathrm{N}$ & Mean & $\begin{array}{c}\text { Std. } \\
\text { Deviation }\end{array}$ \\
\hline Control Class & $\mathbf{3 0}$ & $\mathbf{5 5 , 8 3 3}$ & $\mathbf{6 , 7 0 6}$ \\
\hline $\begin{array}{l}\text { Experimental } \\
\text { Class }\end{array}$ & $\mathbf{3 0}$ & $\mathbf{8 1 , 5}$ & $\mathbf{3 , 7 4 8}$ \\
\hline
\end{tabular}

From table above, the researcher analyzed the data and the mean score of control class is 55,833 while the standard deviation value in the control class is 6,706 and the mean score of Experimental class is 81,5 while the standard deviation in the experimental class is 3,748 .

Testing homogeneity is about equal variances least two or more distributions. Homogeneity test which will be discussed in this paper is a test of homogeneity of variance and test burlett. Homogeneity test is done to determine whether the data in the variables $\mathrm{X}$ and $\mathrm{Y}$ are homogeneous or not.

To test whether the two groups of homogeneous, the following statistical formula used is:

$=\frac{6,706^{2}}{3,478^{2}}$

$$
\mathrm{F}_{\text {count }}=\frac{s_{1}^{2}}{S_{2}^{2}}
$$

$=\frac{44,970}{14,047}$

$=3,201$

Based on the above calculation, it is known that Fcount $=3,201$. Then testing to find out the homogeneity of data obtained with the provision if Fcount $>$ Ftable, then the data is homogeneous.It is known that Ftable for probability 0,05 is 3,16 . It mean that $3,201>$ 3,16 , then it concluded the data is homogeneous.

To calculate the significant influence of the application of scanning techniqueon the students reading comprehension ability, then test the difference between two average that the $t$ test one hand, the right hand with the formula $\mathrm{T}$ test. $\mathrm{T}$ test were used for the variance between the two groups to say homogeneous as follows:

$$
\begin{aligned}
\mathrm{S}_{\mathrm{gab}}=\frac{\left(\mathrm{n}_{\mathrm{e}}-1\right) \mathrm{S}_{\mathrm{y}}^{2}+\left(\mathrm{n}_{\mathrm{k}}-1\right) \mathrm{S}_{\mathrm{x}}^{2}}{\mathrm{n}_{\mathrm{e}}+\mathrm{n}_{\mathrm{k}}-2} & \frac{(30-1) 3,478^{2}+(30-1) 6,706^{2}}{30+30-2} \\
S_{g a b}= & \frac{(29) 14,047+(29) 44,970}{58} \\
S_{g a b}= & \frac{407,337+1304,143}{58}
\end{aligned}
$$


$S_{g a b}=\frac{1711,52}{58}$

$S_{g a b}=29,508$

After knowing the value of Sgab = 29,508 , then next done $t$ test calculation as follows:

$$
\begin{aligned}
& \mathrm{t}_{\text {count }}=\frac{\mathrm{X}_{\mathrm{y}}-\mathrm{X}_{\mathrm{x}}}{\mathrm{s} \sqrt{\frac{1}{\mathrm{n}_{\mathrm{y}}}+\frac{1}{\mathrm{n}_{\mathrm{x}}}}} \\
& t_{\text {count }}=\frac{81,5-55,83}{29,508 \sqrt{\frac{1}{30}+\frac{1}{30}}}
\end{aligned}
$$$$
\frac{25,67}{29,508 \sqrt{0,667}}
$$$$
=\frac{25,67}{29,508(0,258)}
$$$$
=\frac{25,67}{7,619}
$$$$
=3,3693,369
$$

on the above calculation, has been known tcount is 3,369 . To test the hypothesis based on data that has been obtained, then in accordance with the provisions that have been established that the hypothesis accepted if $t_{\text {count }}>t_{\text {table. }}$. Has been known the $t_{\text {table }}$ is 1,671 , then $3,369>1,671$. It concluded the hypothesis is accepted.

Based on data that has been collected through several calculations as mentioned above, it can be discussed some research results as follows:

1. When the students in control class are given learning by applying conventional methods, students do not seem to understand the subject matter completely. It can be seen from the results of student learning to answer the pre-test with the average value is only for 55,833 .

2. In this study, students in the experimental class are given learning by applying Scanning Technique. Enthusiastic students in following the lessons very well, so that students are able to obtain a satisfactory score with an average value of 81,5.

3. Based on the statistical calculation on the homogeneity of the data, has been obtained value 3,201 where the provision of data obtained is homogeneous if $f_{\text {count }}>f_{\text {table. If }}$ $\mathrm{f}_{\text {table }}=3,16$ then criteriaalready accepted.
4. Based on the calculation of the hypothesis test, has been known $t_{\text {count }}$ is 3,369 . To test the hypothesis based on data that has been obtained, then in accordance with the provisions that have been established that the hypothesis accepted if $t_{\text {count }}>t_{\text {table. }}$. Has been known the $t_{\text {table }}$ is 1,671 , then $3,369>$ 1,671. It concluded the hypothesis is accepted.

\section{CONCLUSION}

After the research is done on the tenth grade students of SMA Swasta Melati Binjai In Academic Year 2017/2018 with the number of samples as many as 60 students divided into 2 classes of which control class as much as 30 students and experimental class as many as 30 students. This study uses multiple choice test amounted to 20 questions as a data gathering instrument. After knowing the mean obtained by the respondents in the control class of 55,833 it can be concluded that students' writing comprehension ability is still low and it has been known that the mean data experimental class is 81,5 . It can be concluded that students' reading comprehension in the experimental class is good.

After testing the data hypothesis criteria that have been obtined in the control class and experimental class it has been found that the hypothesis is received, so it can be concluded that the Effect of making Summary on Students' writing Achievement of SMA Swasta Melati Binjai In academic Year 2017/2018. 


\section{REFFERENCES}

Anderson, Mark and friend.Text Types in English 1.South Yarra: Machmillan Education Malaysia. 1997.

Arikunto,Suharsimi. ProsedurPenelitian. Jakarta :RinekaCipta. 2002.

Carnine, D.And friend. Direct Instruction Reading. Ohio :Merril Publishing, Co. 2000.

Chandler, Daniel. An Introduction of Genre Theory, Retrieved on August 12, 2017 at 11.03 from http://www.aber.ac.uk/media/Documen ts/intgenre1.html

Grellet, Francoise.Developing Reading Skills.Cambridge: Cambridge university Press, 1981.

Hamalik, Oemar. Planning Teaching Based on system. Jakarta Bumi : Aksara. 2002.

Harris,A.J. and Friend.How to Increase Reading Ability.New York and London : Longman Inc, 2004.

Hornby,A. S. Oxford Advanced Learners' Dictionary. NY: Oxford University Press. 2010.

Irawan,AgusPurna. Improving students' reading ability through scanning technique at the first grade of SMA Negeri 1 Ladongi.Kolaka : Kolaka University. 2015.

Meyers,A. Gatesways to Academic Writing: Effective Sentences, Paragraph and Essay. New York: Pearson Education. 2005.

Ramelan, Introduction to Linguistic Analysis. Semarang: IKIP Semarang Press, 1992.

Richards, Jack and friends.Longman Dictionary of Applied Linguistics.England: Longman. 1990.

Riduan. Belajar Mudah Penelitian. Bandung : Alfabet. 2010.

Rubin, Dorothy.Diagnosis and Correction in Reading Instruction. New York: CBS College Publishing. 1992.

Surianti.Thesis. Improving Students' Reading Comprehension In Reading Short Story Trough Scanning and Skimming Technique at The First Year Of SMP
Negeri 1 Ladongi. Thesis USN Kolaka. 2013.

Simanjuntak.Developing Reading Skills for EFL Students. Jakarta: Depdibud, 2008.

Sudjana. Prosedur Penelitian. Jakarta : Remaja Rosdakarya. 2010.

Sugiyono.MetodePenelitianPendidikan. Bandung: Alfabeta. 2014.

Swales,J. Genre Analysis.UK: Cambridge University Press. 1990.

Tampubolon, D. P. Kemampuan Membaca: Teknik Membaca Efektif dan Efisien. Bandung : Angkasa.1990.

Tarigan, Henry Guntur. MembacaSebagaiSuatu Keterampilan Berbahasa.Bandung :Angkasa.2008.

Widyamartaya, A.SeniMembacaUntukStudi. Yogyakarta: Kanisius, 1992.

http://pioneer.netserv.chula.ac.th/ pkanchan/ht ml/skim.htm on Wed, March 01, 2017 at $08.30 \mathrm{pm}$. From College Reading and Study Skills andAcademic Reading and Study Skills for International Students.

http://omegahat-

statserv.blogspot.co.id/2012/02/hipotes is.html. Accessed on March 01, 2017. 